\title{
ANALISIS SEMIOTIK DAKWAH ANTARBUDAYA DALAM RUBRIK LENTERA STAIN KUDUS SUARA MERDEKA
}

\author{
Ahmad Zaini
}

\begin{abstract}
Abstrak
Tulisan ini bertujuan untuk mengetahui makna dibalik tanda-tanda verbal yang terkait dengan dakwah antarbudaya yang direpresentasikan dalam rubrik Lentera STAIN Kudus Suara Merdeka edisi Ramadan 1437 H/2016 M serta menjelaskan wujud produk dari dakwah antarbudaya yang dideskripsikan dalam rubrik tersebut. Disamping itu riset ini ingin memberikan manfaat bagi kajian semiotik khususnya pada media cetak (surat kabar) dan umumnya pada media komunikasi. Studi ini menggunakan metode kualitatif dengan analisis berdasarkan teori semiotik Peirce. Hasil penelitian menunjukkan bahwa dalam lima artikel yang dijadikan sebagai subjek riset terdapat beragam makna dakwah dibalik interaksi antara ajaran Islam dengan budaya sebagai sarananya. Selain itu, wujud dakwah antarbudaya termanifestasi dalam bermacam cara tatkala sebagian umat Islam menyambut datangnya bulan Ramadan.
\end{abstract}

Kata kunci: semiotik, dakwah, budaya

\section{A. Pendahuluan}

Paper ini merupakan revisi hasil penelitian di STAIN Kudus tahun 2017. Islam memberikan fungsi yang jelas kepada manusia sebagai makhluk sosial, yakni fungsi ibadah. Maksudnya adalah seluruh aktivitas sosial manusia selalu bermuatan ibadah. Fungsi penciptaan manusia adalah penyembahan kepada Sang Penciptanya, Allah swt. Penyembahan kepada Allah tidak boleh diartikan secara sempit dengan hanya membayangkan aspek ritual yang tercermin dalam salat saja. Penyembahan berarti ketundukan manusia pada hukumhukum Allah dalam menjalankan kehidupan di muka bumi ini, baik yang menyangkut hubungan vertikal dan horisontal (Yusuf, 2002: 51). Dakwah juga merupakan ibadah bagi setiap muslim yang telah mampu baik secara individu maupun kelompok. Dakwah untuk menyembah kepada Zat Allah yang Esa sudah dimulai sejak Nabi Adam a.s. hingga Nabi Muhammad saw.

Pada dasarnya dakwah merupakan proses mengkomunikasikan ajaran Islam kepada khalayak, dalam arti mengajak orang untuk menganut agama Islam. Dalam istilah "mengajak" tersebut, sudah tentu selalu terkandung makna memengaruhi orang lain agar orang lain itu mau dan mampu mengubah sikap, sifat, 
pendapat, dan perilaku sesuai dengan apa yang dikehendaki orang yang mengajaknya. Dalam konteks dakwah, para dai akan selalu berusaha memengaruhi mad'u-nya (Suhandang, 2013: 24).

Dakwah seperti umumnya diketahui, merupakan sebuah sistem untuk mengubah sistem pemahaman, keyakinan dan cara hidup dari kehidupan yang tidak baik menuju sistem pemahaman dan keyakinan akan kehidupan yang lebih baik. Hal ini seperti dakwah yang pernah dilakukan oleh Nabi saw. untuk menciptakan kondisi masyarakat yang beradab dengan menanamkan keyakinan tauhidullah, yaitu suatu keyakinan terhadap Allah yang Esa. Pengabdian kepadanya melahirkan perilaku saleh, perilaku yang humanis, peduli terhadap nasib sesamanya (Enjang AS \& Tajiri, 2009: 85). Lebih jelasnya dakwah yang disampaikan oleh para dai memiliki tujuan-tujuan yang ingin diraih, yaitu menuju kehidupan yang lebih baik, baik di dunia maupun di akhirat.

Untuk menyampaikan tujuan nilainilai Islam tersebut kepada para mad'u ada bermacam-macam cara yang bisa dilakukan oleh para dai, diantaranya melalui media. Media adalah alat atau sarana yang dipergunakan dalam komunikasi antar manusia untuk menyampaikan informasi, berita dan pesan (Puteh (Ed.), 2006: 102). Selama ini, beragam jenis media komunikasi telah digunakan oleh para dai untuk berdakwah, semisal media cetak yang meliputi surat kabar, buku, majalah atau media elektronik semisal televisi, radio, film, dan sebagainya. Masing-masing media memiliki karakteristik dan keunikan tergantug dari situasi dan kondisinya.

Surat kabar (koran) adalah salah satu media cetak yang dapat digunakan untuk menyampaikan informasi, termasuk nilai-nilai keislaman. Sebagai media cetak, surat kabar memiliki beberapa kelebihan disamping kelemahan. Kelebihan surat kabar diantaranya: jangkauannya luas, dapat dibaca kapanpun dan dimanapun, bisa dibaca kembali di lain waktu, dan ulasannya lebih mendalam tergantung tema yang diangkat. Sedang kelemahannya, yaitu: hanya terbatas pada kalangan tertentu, berita yang disampaikan terkadang sudah ketinggalan dengan media elektronik, dan hanya terfokus pada satu arah.

Salah satu surat kabar yang terbit di Indonesia tepatnya Jawa Tengah adalah Suara Merdeka. Rubrik "Lentera STAIN Kudus" adalah salah satu kolom yang muncul pada bulan Ramadan. Nampaknya, tema-tema yang diangkat selama bulan Ramadan 1437 H/2016 M tentang Islam dan budaya Indonesia, khususnya Jawa. Hal ini dapat dilihat secara sekilas dari judul-judul yang tertulis pada setiap harinya. Keanekaragaman topik yang ditampilkan menjadi menarik untuk ditelaah lebih dalam karena 
sebenarnya Islam dapat ditinjau dari perspektif ilmu yang multidisiplin, termasuk budaya. Islam bukan hanya ritual ibadah (fikih) yang termanifestasikan dalam amaliah sehari-hari. Ajaran Islam mencakup segala lini kehidupan yang terangkum dalam hablumminallah dan hablumminannas.

Kajian tentang rubrik dalam surat kabar dengan pendekatan semiotik, khususnya dalam perspektif Peirce telah dibahas dan diulas oleh para peneliti. Beberapa penelitian yang telah dikaji, pertama, Hidayati (2011) meneliti tentang Analisis Semiotika terhadap Rubrik Mode pada Majalah Ummi. Hasil penelitiannya menggambarkan hubungan antara penanda dan petanda dalam rubrik mode yang terdapat dalam majalah Ummi. Bahwa keempat foto yang diteliti memberikan pengertian bahwa agama tidak pernah melarang manusia untuk mengikuti mode karena mode dan seni adalah salah satu pengejawantahan dari budaya, sedangkan budaya adalah bagian primer dari kehidupan manusia.

Kedua, Adawiyah (2015) mengkaji tentang Pesan Dakwah melalui Buletin atTakhobbar Edisi 128 dan 129 Bulan Januari 2015 (Analisis Semiotik Charles Sanders Peirce). Hasil penelitiannya menjelaskan bahwa kisah peringatan Maulid Nabi Muhammad saw. sebagai gambaran tentang kehidupan Rasulullah, akhlak beliau kepada Allah, akhlak beliau kepada sesama juga memahami tentang arti cinta atau bukti cinta kepada Rasulullah saw. Pada tahap kedua, peneliti melihat bahwa dalam kisah tersebut terdapat pesan-pesan dakwah seperti pesan akidah, syariah dan akhlak. Pesan akidah meliputi arti tentang keimanan, dalam hal ini yang dimaksudkan adalah beriman kepada Rasul. Sedangkan pesan syariahnya sebagai seorang muslim yang memanfaatkan hablumminannas untuk menjadi manusia yang bermanfaat bagi orang lain. Kemudian pesan akhlaknya yakni akhlak Nabi Muhammad saw. kepada Allah, dan juga kepada sesama. Dari kedua riset yang telah dipaparkan tersebut, maka paper ini ada persamaan sekaligus perbedaan. Perbedaannya terletak pada objek yang akan dikaji. Objek yang dijadikan kajian dalam riset ini adalah rubrik Lentera STAIN Kudus yang muncul dalam kolom khusus surat kabar Suara Merdeka pada bulan Ramadan 1437 $\mathrm{H} / 2016 \mathrm{M}$.

Studi ini bertujuan untuk mengetahui makna dibalik tanda-tanda verbal terkait dengan dakwah antarbudaya yang direpresentasikan dalam rubrik Lentera STAIN Kudus Suara Merdeka edisi Ramadan 1437 H/2016 M serta menjelaskan wujud produk dari dakwah antarbudaya yang dideskripsikan dalam rubrik tersebut. Disamping itu kajian ini ingin memberikan manfaat bagi kajian semiotik khususnya pada media cetak (surat kabar) dan umumnya pada media 
komunikasi. Studi ini menggunakan metode kualitatif dengan analisis berdasarkan teori semiotik Peirce. Adapun data primer diperoleh dari kliping koran rubrik Lentera STAIN Kudus Suara Merdeka edisi bulan Ramadan tahun 2016. Setidaknya ada 17 artikel yang berkaitan dengan dakwah antarbudaya dalam edisi ini. Namun, paper ini hanya akan menggunakan 5 artikel saja sebagai sampel representasi dari dakwah antarbudaya yang termuat dalam tabel di bawah ini.

Tabel 1. Lima Artikel "Lentera STAIN Kudus”, Ramadan 2016

\begin{tabular}{|c|c|c|c|}
\hline No & Judul & Penulis & Terbit \\
\hline 1 & $\begin{array}{l}\text { Tradisi } \\
\text { Pasanan } \\
\text { Ajarkan } \\
\text { Cinta dan } \\
\text { Ketulusan }\end{array}$ & Nur Said & $\begin{array}{l}7 \text { Juni } \\
2016\end{array}$ \\
\hline 2 & $\begin{array}{l}\text { Tongthek } \\
\text { Manifestasi } \\
\text { Kerukunan }\end{array}$ & $\begin{array}{l}\text { Moh } \\
\text { Sugiharyadi }\end{array}$ & $\begin{array}{l}13 \\
\text { Juni } \\
2016\end{array}$ \\
\hline 3 & $\begin{array}{l}\text { Filantropi } \\
\text { Islam dalam } \\
\text { Takjil }\end{array}$ & $\begin{array}{l}\text { Zaimatus } \\
\text { Sa'diyah }\end{array}$ & $\begin{array}{l}14 \\
\text { Juni } \\
2016\end{array}$ \\
\hline 4 & $\begin{array}{l}\text { Ramadan di } \\
\text { Kudus Kulon }\end{array}$ & $\begin{array}{l}\text { Ahmad } \\
\text { Fatah }\end{array}$ & $\begin{array}{l}25 \\
\text { Juni } \\
2016\end{array}$ \\
\hline 5 & $\begin{array}{l}\text { Malam } \\
\text { Selikuran } \\
\text { dan } \\
\text { Akulturasi } \\
\text { Budaya }\end{array}$ & Eko Sumadi & $\begin{array}{l}27 \\
\text { Juni } \\
2016\end{array}$ \\
\hline
\end{tabular}

\section{B. Hasil dan Pembahasan}

\section{Dakwah Antarbudaya}

Keanekaragaman suku dan budaya telah diterangkan dalam surat alHujurat ayat 13, yaitu: "Hai manusia, essungguhnya Kami menciptakan kamu dari seorang laki-laki dan seorang perempuan dan menjadikan kamu berbangsa-bangsa dan bersuku-suku supaya kamu saling kenal-mengenal. Sesungguhnya orang yang paling mulia diantara kamu disisi Allah ialah orang yang paling taqwa diantara kamu. Sesungguhnya Allah Maha mengetahui lagi Maha Mengenal." Secara tekstual ayat tersebut menerangkan penciptaan manusia yang berasal dari beragam suku bangsa yang berimplikasi pada perbedaan dalam budaya dan adat istiadat.

Shihab (2012: 617-618) menjelaskan bahwa kata ta'arafu memiliki makna timbal balik yang berarti saling mengenal. Semakin kuat pengenalan satu pihak kepada selainnya, semakin terbuka peluang untuk saling memberi manfaat. Perkenalan itu dibutuhkan untuk saling menarik pelajaran dan pengalaman pihak lain guna meningkatkan ketakwaan kepada Allah swt. yang dampaknya tecermin pada kedamaian dan kesejahteraan hidup duniawi dan kebahagiaan ukhrawi. Suku dan budaya bangsa yang beragam ini harus dijaga dan dipupuk sehingga tidak terjadi konflik horisontal, salah satunya melalui dakwah. Yaitu dakwah yang dapat memberikan pencerahan kepada khalayak bahwa sejatinya manusia diciptakan terdiri atas beragam ras dan adat istiadat.

Dakwah dapat diartikan sebagai mengkomunikasikan ajaran Islam, dalam arti mengajak dan memanggil umat manusia agar menganut ajaran Islam, 
memberi informasi mengenai amar makruf dan nahi mungkar agar dapat tercapai kebahagiaan di dunia dan di akhirat serta terlaksana ketentuan Allah (Suhandang, 2013: 12). Sedang dakwah antarbudaya diartikan sebagai proses dakwah yang mempertimbangkan keragaman budaya antar dai (subjek dakwah) dan mad'u (objek dakwah) serta keragaman penyebab terjadinya gangguan interaksi pada tingkat intra dan antarbudaya agar pesan dakwah dapat tersampaikan dengan tetap terpeliharanya situasi damai dan terkendali (Aripudin, 2012: 133). Wujud dari dakwah antarbudaya tampak ketika terjadi proses interaksi antara nilai Islam dengan budaya-budaya lokal, akan menghasilkan wujud budaya Islami yang tidak bertentangan dengan masingmasing nilai (resistensi), terjadi Pambauran (akulturasi), penerimaan salah satunya (receptio) sehingga menimbulkan hegemoni nilai budaya atau terjadi perpaduan yang mengisi (komplementer) (Aripudin, 2012: 134).

Agar dakwah antarbudaya memperoleh hasil yang maksimal, maka dai harus melaksanakan tugasnya dengan profesional. Dai harus memiliki kompetensi dalam melakukan praktik dakwah antara lain piawai melaksanakan tugas sesuai bidang keahliannya dalam dakwah (tablig, irsyad, tadbir dan tathwir); piawai merencana kegiatan dakwah; piawai dalam memformulasikan materi dakwah dan penyampaiannya; serta piawai dalam menggunakan metode dan media dakwah.

a. Piawai dalam menggunakan metode dakwah, didasarkan sekurangkurangnya pada pemahaman standar metode, yakni dalam penggunaannya mempertimbangkan penggunaan metode yang tepat dan relevan. Metode ini tentu ditetapkan sesuai dengan kondisi medan dan objek dakwah. Misal dalam tabligh, jika objek tablighnya anakanak, metode cerita (qishah) dan pengulangan akan sangat tepat, esdangkan jika objeknya kalangan akademisi maka dialog merupakan metode yang paling tepat.

b. Piawai dalam menggunakan media dakwah, maksudnya dai dituntut untuk melek teknologi, tidak gaptek, memahami karakteristik media, mampu mendesain dakwah melalui media tertentu. Selain itu dai juga sebaiknya mampu menjalin kerjasama dengan praktisi seni dan pecinta musik, bekerjasama dengan para sineas, seniman kaligrafi, lukisan dan ukiran.

c. Piawai menyusun materi dakwah. Sebelum dakwah dilangsungkan, seorang dai terlebih dahulu membuat konsep dan menyusun materi dakwah yang akan dilaksanakannya. Konsep mengacu kepada standar pembuatan materi dakwah antara lain: merujuk kepada al-Quran dan hadis, memperkaya materi dengan penafsiran mufassir, kaidah-kaidah fikih, ungkapan- 
ungkapan bijak, kisah-kisah teladan, tidak menjelek-jelekkan kelompok berbeda, serta improvisasi sesuai dengan topik inti (Enjang AS \& Tajiri, 2009: 100-101).

\section{Teori Semiotik Peirce}

Peirce memaknai semiotik sebagai studi tentang tanda dan segala yang berhubungan dengan tanda. Tanda tidak hanya melekat pada bahasa dan kebudayaan, tetapi juga menjadi sifat intrinsik pada seluruh fenomena alam. Melalui tanda, manusia mampu memaknai kehidupan dengan realitas. Di sini, bahasa menempati posisi terpenting sebagai sistem tanda yang paling fundamental bagi manusia. Adapun tanda-tanda nonverbal, seperti gerak-gerik serta beragam praktik sosial konvensional lain, dipandang sebagai sejenis bahasa yang tersusun dari tanda-tanda bermakna yang dikomunikasikan atas dasar relasi-relasi (Rusmana, 2014: 107).

Peirce yang dianggap sebagai
pendiri tradisi semiotik Amerika menjelaskan model pemaknaan secara singkat sebagaimana dijelaskan oleh Fiske (2012: 70) yang mengatakan bahwa sebuah tanda adalah sesuatu yang bagi seseorang mewakili sesuatu di dalam beberapa hal atau kapasitas tertentu. Tanda menuju pada seseorang, artinya menciptakan di dalam benak orang tersebut tanda yang sepadan, atau mungkin juga tanda yang lebih sempurna.
Tanda yang tercipta dibenak tersebut dinamakan interpretant (hasil interpretasi) dari tanda yang pertama. Tanda mewakili sesuatu, objeknya. Tiga istilah dari Peirce atau yang dikenal dengan teori segitiga makna (triangle meaning) yang terdiri atas tanda (sign), objek (object), dan interpretan (interpretant) dapat dijelaskan dalam gambar berikut ini:

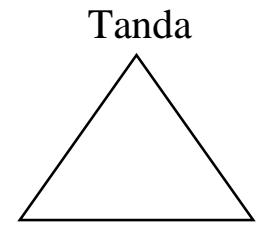

Interpretan Objek

Gambar 1.

Elemen-Elemen Makna menurut Peirce

Contoh penerapan model gambar di atas untuk menganalisis makna sosial sebuah tanda, maka dapat dilihat pada makna lirik lagu berjudul Bongkar ciptaan Iwan Fals. Adapun gambarnya sebagai berikut:

Gambar 2.

Triangle of Meaning dalam Lirik Lagu

"Bongkar"

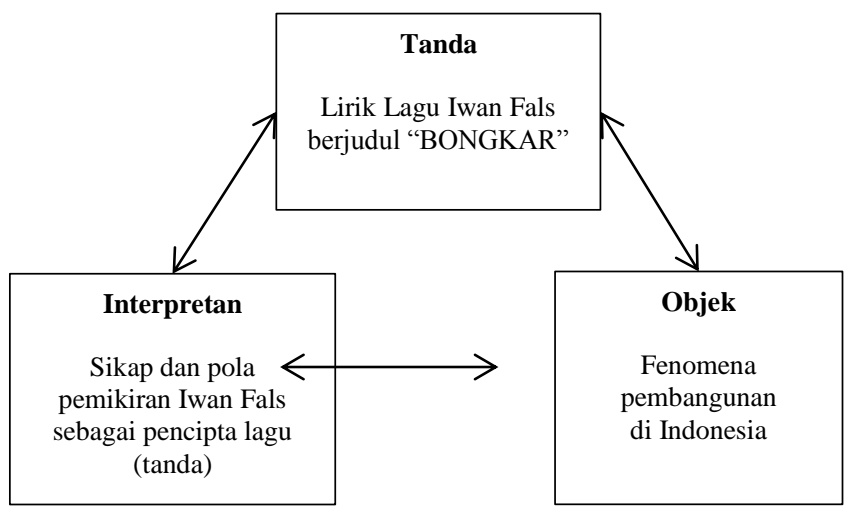

Iwan Fals merupakan penyanyi yang terkenal dengan lagu-lagu bertema 
kritik sosial. Dia adalah penyanyi yang berangkat dari bawah, bahkan pernah menjadi pengamen jalanan. Pengalaman hidupnya itulah yang akhirnya banyak mewarnai atau menjiwai sikapnya dalam menciptakan lagu. Banyak lagu yang diciptakannya berisi kritik terhadap ketidakadilan, perilaku sewenang-wenang penguasa ataupun ketidakbecusan aparat negara dalam melayani masyarakat sehingga mengakibatkan rakyat menderita. Ada sebuah lagu yang diciptakannya di tahun 1980-an berjudul Bongkar. Lagu ini dinyanyikannya bersama kelompok musik "Kantata Takwa". Pada dasarnya lagu tersebut merupakan ekspresi sikap dan pemikiran Iwan dalam memahami fenomena sekitarnya, yaitu fenomena pembangunan di Indonesia. Salah satu lirik dalam lagu tersebut berbunyi:

Sabar... sabar... sabar dan tunggu Itu jawaban yang kami terima Ternyata kita harus ke jalan Singkirkan karang yang berdiri menghadang

Ooya.. oya.. oya bongkar $2 x$

Apabila dianalisis dengan semiotik Peirce, maka dapat dilakukan analisis yang terlihat pada table berikut ini:
Tabel 2. Analisis Semiotik Terhadap Lirik Lagu Bongkar

\begin{tabular}{|l|c|l|}
\hline \multicolumn{1}{|c|}{ Interpretan } & \multicolumn{1}{c|}{ Objek } & \multicolumn{1}{c|}{ Tanda } \\
\hline Pemikiran seorang & - Fenomena & Lirik lagu \\
Iwan Fals terhadap & penggusuran & "Bongkar": \\
kondisi masyarakat & - Maraknya & Sabar-sabar- \\
Indonesia termasuk di & demosntrasi & sabar dan \\
dalamnya proses & - Sikap & tunggu. \\
pembangunan. Iwan & pemerintah & Itu jawaban \\
merasa pembangunan & yang tidak & yang kami \\
yang dilakukan tidak & peduli & terima. \\
adil, belum membawa & - Tidak & Ternyata kita \\
kemakmuran, & berfungsinya & harus ke jalan \\
dinikmati oleh orang- & wakil rakyat di & singkirkan \\
orang kaya sedangkan & DPR & karang yang \\
masyarakat miskin & & berdiri \\
sengsara. Pemikiran & & menghadang. \\
dan sikap ini tidak & & \\
terlepas latarbelakang & & \\
Iwan yang sejak muda & & \\
bergaul dengan & & \\
kesengsaraan rakyat, & & \\
yaitu saat menjadi & & \\
pengamen jalanan. & & \\
\hline
\end{tabular}

Analisis tersebut tentu sifatnya subjektif, seolah-olah peneliti mengetahui pemikiran subjek yang ditelitinya. Karenanya, sudah seharusnya peneliti menjelaskan konteks sosio budaya, konsep-konsep dan data-data guna menjelaskan analisis dan interpretasinya (Kriyantono, 2012: 268-269).

\section{Gambaran Umum tentang}

\section{Rubrik "Lentera STAIN Kudus"} "Lentera STAIN Kudus" adalah salah satu kolom yang muncul pada bulan Ramadan. Nampaknya, tema-tema yang diangkat selama bulan Ramadan 1437 H/2016 M tentang Islam dan budaya Indonesia. Hal ini dapat dilihat secara sekilas dari judul-judul yang tertulis pada setiap harinya. Keanekaragaman judul yang ditampilkan menjadi menarik untuk ditelaah lebih dalam karena sebenarnya Islam dapat ditinjau dengan beragam 
perspektif, termasuk budaya. Islam bukan

hanya ritual ibadah (fikih) yang

termanifestasikan dalam amaliah sehari-

hari. Ajaran Islam mencakup segala lini kehidupan yang terangkum dalam

hablumminallah dan hablumminannas.

\section{Makna Tanda-tanda Verbal}

pada Dakwah Antarbudaya

yang Digambarkan dalam

Rubrik Lentera STAIN Kudus

\section{Suara Merdeka}

Pertama, analisis semiotik tar-

hadap artikel "Tradisi Pasanan Ajarkan

Cinta dan Ketulusan" oleh Nur Said. Said

(Juni 7, 2016) menyatakan bahwa:

"Dalam tradisi pasanan setiap santri bebas memilih guru dan jenis kitab yang diajarkan karena dalam setiap pesantren biasanya menye-lenggarakan kajian sejumlah kitab-kitab tertentu yang diampu oleh para kiai setempat. Ngaji pasanan terbuka untuk umum baik dari santri yang tinggal di pesantren maupun santri kalong yang datang ketika mengaji dan pulang setelah mengaji. Yang menarik tradisi pasanan dibuka secara gratis."
Tabel 3. Analisis Semiotik Artikel "Tradisi Pasanan Ajarkan Cinta dan Ketulusan"

\begin{tabular}{|c|c|c|}
\hline Interpretan & Objek & Tanda \\
\hline $\begin{array}{l}\text { Ramadan di Indonesia } \\
\text { disambut dengan tradisi } \\
\text { yang berkembang di } \\
\text { masing-masing daerah. } \\
\text { Terdapat sinergi antara } \\
\text { agama dan budaya, } \\
\text { keduanya dapat berjalan } \\
\text { secara beriringan. } \\
\text { Budaya yang berkembang di } \\
\text { saat bulan Ramadan di } \\
\text { antaranya adalah } \\
\text { dandangan, dukderan, } \\
\text { nyadran. Semisal tradisi } \\
\text { dandangan untuk } \\
\text { dimaksudkan untuk } \\
\text { mengenalkan kepada } \\
\text { masyarakat bahwa awal } \\
\text { mulanya dandangan ini } \\
\text { berkaitan dengan penentuan } \\
\text { datangnya bulan Ramadan } \\
\text { disamping itu diramaikan } \\
\text { dengan pasar rakyat } \\
\text { sebagai upaya untuk } \\
\text { meningkatkan ekonomi } \\
\text { rakyat. } \\
\text { Pada bulan Ramadan tradisi } \\
\text { pasanan yang dibuka secara } \\
\text { gratis bagi setiap santri dan } \\
\text { masyarakat umum. } \\
\text { Ramadan memang harus } \\
\text { diisi dengan kegiatan positif } \\
\text { sehingga akan lebih } \\
\text { bermakna. }\end{array}$ & $\begin{array}{l}\text { - } \text { Tradisi } \\
\text { menyambut } \\
\text { bulan } \\
\text { Ramadan } \\
\text { - Tradisi } \\
\text { Islam } \\
\text { Nusantara, } \\
\text { diantaranya: } \\
\text { pasanan. }\end{array}$ & $\begin{array}{l}\text { Judul artikel } \\
\text { "Tradisi } \\
\text { Pasanan } \\
\text { Ajarkan } \\
\text { Cinta dan } \\
\text { Ketulusan" }\end{array}$ \\
\hline
\end{tabular}

Kedua, analisis semiotik terhadap artikel "Tongthek Manifestasi Kerukunan" oleh Moh Sugiharyadi. Dalam tulisan tersebut, Sugiharyadi (Juni 13, 2016) menyatakan bahwa:

"Tong-tong klek dalam hal tersebut, memiliki nilai-nilai yang dapat memberi sumbangan dalam segala aspek tersebut. Karena itu tidak berlebihan jika terdapat pemahaman tong-tong klek merupakan manifestasi kerukunan umat beragama. Alasan ini didasari tiga hal pokok yang dapat ditonjolkan dalam tinjauan Islam Nusantara, yakni dapat menjadi pendorong bagi peningkatan sumber daya manusia yang memahami pentingnya kerukunan, 
untuk meningkatkan partisipasi dalam karya dan kreasi mereka, dan sebagai penanam nilai-nilai."

Tabel 4. Analisis Semiotik Artikel "Tongthek Manifestasi Kerukunan"

\begin{tabular}{|c|c|c|}
\hline Interpretan & Objek & Tanda \\
\hline $\begin{array}{l}\text { Tradisi tongthek yang } \\
\text { berkembang di } \\
\text { masyarakat sudah } \\
\text { menjadi salah satu } \\
\text { kegiatan yang muncul } \\
\text { pada bulan Ramadan. } \\
\text { Kesenian rakyat ini } \\
\text { digunakan untuk } \\
\text { membangunkan sahur } \\
\text { bagi orang-orang yang } \\
\text { masih terlelap dalam } \\
\text { mimpinya. Tradisi } \\
\text { tongthek selalu ditunggu } \\
\text { kehadirannya oleh } \\
\text { masyarakat ini } \\
\text { membuktikan bahwa } \\
\text { budaya ini dapat } \\
\text { dijadikan sebagai sarana } \\
\text { silaturahmi para penabuh } \\
\text { tongthek dengan warga } \\
\text { yang dibangunkannya. } \\
\text { Tradisi tongthek juga } \\
\text { sebagai sarana } \\
\text { membentuk kerukunan } \\
\text { antar mereka, karena } \\
\text { sama-sama memiliki misi } \\
\text { dan tujuan yang sama } \\
\text { untuk membangunkan } \\
\text { orang-orang untuk sahur } \\
\text { sehingga tidak terlambat } \\
\text { atau habis waktu untuk } \\
\text { sahur. }\end{array}$ & $\begin{array}{l}\text { - Tradisi } \\
\text { Tongthek. } \\
\text { - Kerukunan. }\end{array}$ & $\begin{array}{l}\text { Judul artikel } \\
\text { "Tongthek } \\
\text { Manifestasi } \\
\text { Kerukunan" }\end{array}$ \\
\hline
\end{tabular}

Ketiga, analisis semiotik terhadap artikel "Filantropi Islam dalam Takjil" oleh Zaimatus Sa'diyah. Sa'diyah (Juni 14, 2016) menyatakan dalam artikelnya:

"Kesadaran akan ajaran filantropi dalam Islam mencapai puncaknya saat Ramadan. Ini tidak lepas dari optimisme yang membubung karena janji-janji pasti tentang kemuliaan dan balasan kebaikan berlipat ganda yang telah diberikan oleh Allah kepada umat Islam melalui Nabi Muhammad saw. Dalam konteks Islam Nusantara, optimisme untuk mendapatkan kemuliaan dan kebaikan berlipat ganda itu salah satunya terlihat dalam semarak mensyiarkan ajaran filantropi Islam dalam tradisi takjil."

\section{Tabel 5. Analisis Semiotik Artikel "Filantropi Islam dalam Takjil"}

\begin{tabular}{|c|c|c|}
\hline Interpretan & Objek & Tanda \\
\hline $\begin{array}{l}\text { Takjil yang secara } \\
\text { bahasa diartikan sebagai } \\
\text { menyegerakan sesuatu } \\
\text { berkembang maknanya } \\
\text { sebagai hidangan atau } \\
\text { menu buka puasa yang } \\
\text { disediakan untuk orang- } \\
\text { orang yang akan berbuka } \\
\text { puasa di waktu azan } \\
\text { magrib tiba. Istilah takjil } \\
\text { sudah menjadi tradisi di } \\
\text { hampir setiap masjid di } \\
\text { seantero negeri. Menu } \\
\text { yang dihidangkan juga } \\
\text { beragam mulai yang } \\
\text { sederhana hingga menu } \\
\text { yang berat. Semisal } \\
\text { kurma, teh hangat, } \\
\text { gorengan, kolak, es } \\
\text { buah, hingga menu yang } \\
\text { berat yaitu nasi dan lauk } \\
\text { pauknya. Takjil } \\
\text { merupakan sunah } \\
\text { Rasulullah, agar ketika } \\
\text { waktu azan magrib } \\
\text { datang, segera } \\
\text { membatalkan puasanya, } \\
\text { karena itu perbuatan } \\
\text { yang telah dicontohkan } \\
\text { oleh beliau Rasulullah } \\
\text { saw. Takjil juga } \\
\text { merupakan bentuk } \\
\text { filantropi dalam Islam } \\
\text { karena sebagai bentuk } \\
\text { bantuan bagi orang- } \\
\text { orang yang sedang } \\
\text { bepergian namun belum } \\
\text { sempat berbuka. }\end{array}$ & $\begin{array}{l}\text { - Filantropi } \\
\text { Islam } \\
\text { - Takjil } \\
\text { (menyediak } \\
\text { an buka } \\
\text { puasa) }\end{array}$ & $\begin{array}{l}\text { Judul artikel } \\
\text { "Filantropi } \\
\text { Islam dalam } \\
\text { Takjil" }\end{array}$ \\
\hline
\end{tabular}

\section{Keempat, analisis semiotik} terhadap artikel "Ramadan di Kudus Kulon" oleh Ahmad Fatah. Fatah (Juni 25, 2016) menegaskan dalam tulisannya:

"Syiar Ramadan di Kudus Kulon tidak hanya terlihat selama Ramadan. Sebelum Ramadan tiba, dikenal dengan adanya 
istilah Dandangan. Tradisi

Dandangan ini awalnya pada

zaman dahulu masyarakat

Kudus berkumpul di depan

Menara Masjid al-Aqsha yang

kini populer dengan sebutan

Masjid Menara Kudus,

menunggu pengumuman awal

puasa Ramadan dari Syeikh

Dja'far Sodiq (Sunan Kudus).

Sunan Kudus adalah pemimpin agama Islam di Kudus dan ahli falak. Setelah keputusan awal puasa itu disampaikan oleh Sunan Kudus, maka dipukullah beduk di Masjid Menara Kudus yang bunyinya "dang-dangdang". Dari suara beduk itulah, istilah Dandangan lahir."

\section{Tabel 6. Analisis Semiotik Artikel "Ramadan di Kudus Kulon"}

\begin{tabular}{|c|c|c|}
\hline Interpretan & Objek & Tanda \\
\hline $\begin{array}{l}\text { Sambutan terhadap } \\
\text { datangnya bulan } \\
\text { Ramadan dimaknai } \\
\text { berbeda bagi setiap } \\
\text { daerah. Bahkan di satu } \\
\text { kota bisa memiliki } \\
\text { bermacam-macam } \\
\text { cara. Salah satunya } \\
\text { adalah Kudus Kulon. Di } \\
\text { Kudus Kulon terdapat } \\
\text { tradisi yang disebut } \\
\text { dengan Dandangan. } \\
\text { Awal tradisi Dandangan } \\
\text { terjadi pada zaman } \\
\text { Sunan Kudus hidup. } \\
\text { Menjelang datangnya } \\
\text { bulan Ramadan, } \\
\text { dahulu masyarakat } \\
\text { Kudus berkumpul di } \\
\text { depan Menara Masjid } \\
\text { al-Aqsha yang kini } \\
\text { populer dengan } \\
\text { sebutan Masjid Menara } \\
\text { Kudus, menunggu } \\
\text { pengumuman awal } \\
\text { puasa Ramadan Sunan } \\
\text { Kudus. Setelah } \\
\text { diumumkan oleh } \\
\text { Kanjeng Sunan Kudus } \\
\text { pada malam hari, maka } \\
\text { esoknya umat Islam } \\
\text { melaksanakan puasa } \\
\text { Ramadan. Tradisi } \\
\text { Dandangan ini masih } \\
\text { dilestarikan oleh } \\
\text { pemerintah Kabupaten } \\
\text { Kudus hingga saat ini, } \\
\text { disamping wasilah } \\
\text { untuk silaturahmi } \\
\text { sebagai sarana untuk } \\
\text { menjaga warisan dari }\end{array}$ & $\begin{array}{l}\text { - Ramadan } \\
\text { - Kudus } \\
\text { Kulon }\end{array}$ & $\begin{array}{l}\text { Judul artikel } \\
\text { "Ramadan di } \\
\text { Kudus } \\
\text { Kulon" }\end{array}$ \\
\hline
\end{tabular}

\begin{tabular}{|l|l|l|}
\hline Sunan Kudus serta & & \\
juga sebagai sarana & & \\
hiburan bagi & & \\
masyarakat Kudus dan & & \\
sekitarnya. & & \\
\hline
\end{tabular}

Kelima, analisis semiotik terhadap artikel "Malam Selikuran dan Akulturasi Budaya" oleh Eko Sumadi. Sumadi (Juni 27, 2016) menyatakan bahwa:

"Sebagai contoh, salah satu bentuk budaya dengan nilai-nilai religiusitas yang masih dilestarikan oleh masyarakat Jawa hingga saat ini adalah tradisi malam selikuran pada Ramadan. Tradisi ini dilakukan untuk menyemarakkan sepuluh hari terakhir Ramadan. Dalam tradisi Jawa, selikuran berasal dari kata selikur (sebutan bilangan 21), yang maknanya kurang lebih sing linuwih le tafakur. Tafakur artinya mendekatkan diri kepada Allah swt. Dengan begitu, pesan yang terkandung di dalamnya, bahwa ibadah puasa Ramadan di sepuluh hari terakhir harus lebih ditingkatkan kualitasnya, baik dengan memperbanyak sedekah, iktikaf, dan tadarus al-Quran"

\section{Tabel 7. Analisis Semiotik Artike "Malam Selikuran dan Akulturasi Budaya"}

\begin{tabular}{|c|c|c|}
\hline Interpretan & Objek & Tanda \\
\hline $\begin{array}{l}\text { Ramadan menjadi } \\
\text { bulan pendidikan bagi } \\
\text { yang menjalaninya. } \\
\text { Banyak kegiatan yang } \\
\text { dilakukan oleh umat } \\
\text { Islam pada bulan } \\
\text { Ramadan, mulai dari } \\
\text { tadarus al-Quran, } \\
\text { takjil, pengajian } \\
\text { nuzulul Quran, } \\
\text { khataman, salat lail, } \\
\text { dan sebagainya. } \\
\text { Salah satu tradisi yang } \\
\text { sudah membudaya di } \\
\text { sebagian masyarakat } \\
\text { Jawa adalah } \\
\text { selikuran. Tradisi ini } \\
\text { biasanya dilaksanakan } \\
\text { pada sepuluh malam }\end{array}$ & $\begin{array}{ll}\text { - } & \text { Malam } \\
& \text { Selikuran } \\
\text { - } & \text { Akulturasi } \\
& \text { Budaya }\end{array}$ & $\begin{array}{l}\text { Judul artikel } \\
\text { "Malam } \\
\text { Selikuran } \\
\text { dan } \\
\text { Akulturasi } \\
\text { Budaya" }\end{array}$ \\
\hline
\end{tabular}




\begin{tabular}{|l|l|l|}
\hline terakhir di bulan & & \\
Ramadan sebagai & & \\
sarana untuk tafakkur. & \\
Tafakur memiliki & \\
makna sebagai & \\
pendekatan kepada & \\
Allah swt. Hari-hari & \\
terakhir di bulan & \\
Ramadan ibadah dan & \\
amal saleh harus & \\
ditingkatkan kualitas & \\
dan kuantitasnya & \\
sehingga tujuan puasa & \\
yang disebutkan & \\
dalam berbagai ayat & \\
dapat tercapai, yaitu & \\
menjadi orang yang & \\
bertakwa. Banyak & \\
sekali amal saleh yang & & \\
dapat diperbuat pada & & \\
akhir bulan Ramadan, & & \\
semisal iktikaf, & & \\
sedekah, tadarus al- & & \\
Quran, kesemuanya & & \\
itu sebagai wasilah & & \\
untuk mendekatkan & & \\
diri kepada Allah swt. & & \\
dan bentuk & \\
pengabdian seorang & \\
hamba kepada Tuhan- & & \\
Nya. & & \\
\hline
\end{tabular}

5. Wujud Produk dari Dakwah Antarbudaya yang Dinarasikan dalam Rubrik Lentera STAIN Kudus Suara Merdeka

Seperti dijelaskan di atas bahwa wujud produk dari dari dakwah antarbudaya adalah adanya proses interaksi antara nilai Islam dengan budaya-budaya lokal, sehingga terjadi akulturasi budaya setempat dengan nilainilai Islam. Maka pada kesempatan berikut ini, dapat dilihat dalam artikel yang ditulis oleh para penulis mengisyaratkan bahwa bulan Ramadan di Nusantara disambut dengan beragam tradisi yang dibalut dengan nilai-nilai keislaman.

Tabel 8. Wujud Produk Dakwah Antarbudaya

\begin{tabular}{|c|c|c|}
\hline No & $\begin{array}{c}\text { Produk Dakwah } \\
\text { Antarbudaya }\end{array}$ & Judul Artikel \\
\hline
\end{tabular}

\begin{tabular}{|c|c|c|}
\hline 1 & $\begin{array}{l}\text { - } \text { Tradisi } \\
\text { menyambut bulan } \\
\text { Ramadan } \\
\text { - Islam Nusantara } \\
\text { diantaranya: } \\
\text { pasanan. } \\
\end{array}$ & $\begin{array}{l}\text { "Tradisi Pasanan } \\
\text { Ajarkan Cinta dan } \\
\text { Ketulusan" oleh Nur } \\
\text { Said }\end{array}$ \\
\hline 2 & $\begin{array}{l}\text { - Tradisi Tongthek } \\
\text { - Kerukunan }\end{array}$ & $\begin{array}{l}\text { "Tongthek Manifestasi } \\
\text { Kerukunan" oleh Moh } \\
\text { Sugiharyadi }\end{array}$ \\
\hline 3 & $\begin{array}{l}\text { - } \text { Filantropi Islam } \\
\text { - Takjil } \\
\text { (menyediakan } \\
\text { buka puasa) }\end{array}$ & $\begin{array}{l}\text { "Filantropi Islam dalam } \\
\text { Takjil" oleh Zaimatus } \\
\text { Sa'diyah }\end{array}$ \\
\hline 4 & $\begin{array}{l}\text { - Ramadan } \\
\text { - Kudus Kulon }\end{array}$ & $\begin{array}{l}\text { "Ramadan di Kudus } \\
\text { Kulon" oleh Ahmad } \\
\text { Fatah }\end{array}$ \\
\hline 5 & $\begin{array}{l}\text { - Malam Selikuran } \\
\text { - } \text { Akulturasi Budaya }\end{array}$ & $\begin{array}{l}\text { "Malam Selikuran dan } \\
\text { Akulturasi Budaya" } \\
\text { oleh Eko Sumadi }\end{array}$ \\
\hline
\end{tabular}

Lima artikel yang telah diuraikan tersebut nampak dan terlihat adanya budaya dibalut dengan nilai-nilai keislaman dalam setiap tulisannya. Islam yang disebarkan di Nusantara berakulturasi dengan budaya setempat, tradisi yang ada tidak kemudian dihilangkan oleh sebagian umat Islam. Pertama, artikel yang berjudul "Tradisi Pasanan Ajarkan Cinta dan Ketulusan". Wujud dakwah antarbudaya yang terlihat adalah ketika bulan Ramadan datang disambut dengan tradisi yang berkembang di masing-masing daerah. Budaya yang berkembang di saat bulan Ramadan di antaranya adalah dandangan, dukderan, nyadran, besik kubur, padhusan, nyekar. Selain itu, pada bulan Ramadan tradisi ngaji pasanan yang dibuka secara gratis bagi setiap santri dan masyarakat umum. Santri dibebaskan untuk memilih guru dan jenis kitab yang ingin dikaji sesuai keinginan masing-masing santri. Ramadan lebih bermakna bila diisi dengan kegiatan yang bermanfaat. 
Kedua, wujud dakwah antarbudaya dalam artikel "Tongthek Manifestasi Kerukunan" terlihat bahwa tradisi tongthek yang berkembang di masyarakat sudah menjadi salah satu kegiatan yang muncul pada bulan Ramadan. Kesenian rakyat ini digunakan untuk membangunkan sahur bagi orang-orang yang masih terlelap dalam mimpinya. Tradisi tongthek juga sebagai sarana membentuk silaturahmi dan meningkatkan kerukunan antar mereka, karena sama-sama memiliki tujuan yang sama yaitu untuk membangunkan orang-orang untuk sahur sehingga tidak terlambat atau habis waktu untuk sahur.

Ketiga, artikel yang berjudul "Filantropi Islam dalam Takjil" mengisyarakatkan bahwa takjil sudah menjadi tradisi di hampir setiap masjid yang ada di Indoensia khususnya di kotakota besar, bahkan di kota kecamatan. Menu yang dihidangkan juga bermacammacam, mulai yang sederhana hingga menu yang berat. Semisal kurma, teh hangat, gorengan, kolak, es buah, hingga menu yang berat yaitu nasi dan lauk pauknya. Takjil juga merupakan bentuk filantropi dalam Islam karena sebagai bentuk bantuan bagi orang-orang yang sedang berpergian namun belum sempat berbuka.

Kermpat, tulisan "Ramadan di Kudus Kulon" meliputi tentang tradisi yang berkembang di Kudus Kulon. Di Kudus Kulon terdapat tradisi yang disebut dengan
Dandangan. Awal tradisi Dandangan terjadi pada zaman Sunan Kudus hidup. Menjelang datangnya bulan Ramadan, dahulu masyarakat Kudus berkumpul di depan Menara Masjid al-Aqsha yang kini populer dengan sebutan Masjid Menara Kudus, menunggu pengumuman awal puasa Ramadan Sunan Kudus. Setelah diumumkan oleh Kanjeng Sunan Kudus pada malam hari, maka esoknya umat Islam melaksanakan puasa Ramadan.

Kelima, "Malam Selikuran dan Akulturasi Budaya". Wujud dakwah antarbudaya terlihat pada tradisi Selikuran yang sudah membudaya di sebagian masyarakat Jawa. Tradisi ini biasanya dilaksanakan pada sepuluh malam terakhir di bulan Ramadan sebagai sarana untuk tafakur. Tafakur memiliki makna sebagai pendekatan kepada Allah swt. Banyak sekali amal saleh yang dapat diperbuat pada akhir bulan Ramadan, semisal iktikaf, sedekah, tadarus al-Quran, kesemuanya itu sebagai wasilah untuk mendekatkan diri kepada Allah swt. dan bentuk pengabdian seorang hamba kepada Tuhan-Nya.

\section{Penutup}

Dakwah tidak sekedar disampaikan melalui mimbar. Dakwah dapat disampaikan melalui beragam media, di antaranya melalui medium koran. Seperti dalam muatan artikel di rubrik Lentera STAIN Kudus Koran Suara Merdeka, tampak pesan-pesan dakwah 
disebarkan melalui budaya. Setelah menjelaskan lima artikel tersebut, maka dapat disimpulkan bahwa dalam lima artikel yang dijadikan sebagai subjek riset terdapat beragam makna dakwah dibalik interaksi antara ajaran Islam dengan budaya sebagai sarananya. Selain itu, wujud dakwah antarbudaya termanifestasi dalam beragam cara tatkala umat Islam menyambut datangnya bulan Ramadan. Ramadan sebagai kewajiban umat Islam, disambut dengan bermacam-macam tradisi yang sudah berkembang di daerah masing-masing. Beberapa tradisi yang telah berkembang adalah ketika Ramadan tiba ada tradisi ngaji pasanan yang dibuka secara gratis bagi setiap santri dan masyarakat umum, tradisi tongthek yang dijadikan sebagai sarana silaturahmi para penabuh tongthek dengan warga yang dibangunkannya, tradisi takjil sebagai bentuk filantropi dalam Islam, tradisi Dandangan di Kudus Kulon sebagai tanda datangnya bulan Ramadan, serta tradisi Selikuran bagi sebagian masyarakat Jawa yang digunakan sebagai sarana tafakur.

\section{Daftar Pustaka}

Adawiyah, Yani Roifatul. (2015). Pesan Dakwah Melalui Buletin At Takhobbar Edisi 128 dan 129 Bulan Januari 2015 (Analisis Semiotik Charles Sanders Peirce), Skripsi, Fakultas Dakwah dan Komunikasi, Universitas Islam Negeri Sunan Ampel, Surabaya, diakses 29 Januari 2017, dari http://digilib.uinsby.ac.id/3104/1/Ab strak.pdf.

Aripudin, Acep. (2012). Dakwah Antarbudaya, Bandung: PT Remaja Rosdakarya.

Anwar Yusuf, Ali. (2002). Wawasan Islam, Bandung: Pustaka Setia.

AS, Enjang \& Tajiri, Hajir. (2009). Etika Dakwah: Panduan Para Juru Dakwah (Suatu Pengekatan Teoritik dan Aplikatif), Bandung: Widya Padjadjaran.

Fatah, Ahmad. (2016, Juni 25). Ramadan di Kudus Kulon. Suara Merdeka.

Fiske, John. (2012). Pengantar IImu Komunikasi, diterjemahkan oleh Hapsari Dwiningtyas, dari Introduction to Communication Studies, Jakarta: Rajawali Pers.

Hidayati, Noor. (2011). Analisis Semiotika terhadap Rubrik Mode pada Majalah Ummi”, Skripsi, Fakultas IImu Dakwah dan IImu Komunikasi, Universitas Islam Negeri Syarif Hidayatullah, Jakarta, diakses 29 Januari 2017, dari http://repository.uinjkt.ac.id/dspace /bitstream/123456789/5019/1/NO OR\%20HIDAYATI-FDK.PDF. Kriyantono, Rachmat. (2012). Teknik Praktis Riset Komunikasi: Disertai Contoh Praktis Riset Media, Public Relations, Advertising, Komunikasi Organisasi, Komunikasi 
Pemasaran, Jakarta: Kencana Prenada Media Group.

Puteh, M. Jakfar (Ed.). (2006). Dakwah Tekstual dan Kontekstual: Peran dan Fungsinya dalam Pemberdayaan Ekonomi Umat, Yogyakarta: AK Group.

Suhandang, Kustadi. (2013). IImu Dakwah, Bandung: PT Remaja Rosdakarya.

Shihab, M. Quraish. (2012). Tafsir alMishbah: Pesan, Kesan, dan Keserasian al-Quran, Jakarta: Lentera Hati.

Rusmana, Dadan. (2014) Filsafat Semiotika: Paradigma, Teori, dan
Metode Interpretasi Tanda: dari Semiotika Struktural Hingga Dekonstruksi Praksis, Bandung: Pustaka Setia.

Said, Nur. (2016, Juni 7). Tradisi Pasanan Ajarkan Cinta dan Ketulusan. Suara Merdeka.

Sa'diyah, Zaimatus. (2016, Juni 14). Filantropi Islam dalam Takjil. Suara Merdeka.

Sugiharyadi, Moh. (2016, Juni 13). Tongthek Manifestasi Kerukunan. Suara Merdeka.

Sumadi, Eko. (2016, Juni 27). Malam Selikuran dan Akulturasi Budaya. Suara Merdeka. 